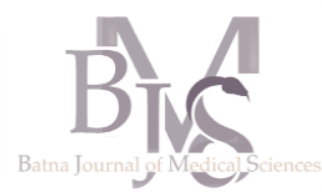

\title{
Allogeneic hematopoietic stem cell transplantation
}

\author{
Greffe allogénique de cellules souches hématopoïétiques
}

\author{
Assia Alem, Farah Bouamama, Mohamed Brahimi, Mohamed Amine Bekadja
}

On behalf of the Transplant Comity of the EHU Oran

Hematology and Cell Therapy Department, EHU "1er

Novembre 1954" Oran, Algeria.

\section{Corresponding author:}

Mohamed BRAHIMI

bmw73dz@yahoo.fr

DOI :https://doi.org/10.48087/ B]MStfa.2017.4118

This is an open access article distributed under the terms of the Creative Commons Attribution International License (CC BY 4.0), which permits unrestricted use, distribution, and reproduction in any medium or format, provided the original author and journal are appropriately credited.

\section{ABSTRACT}

Allogeneic hematopoietic stem cell transplantation is a potentially curative procedure for a variety of malignant and non-malignant diseases of the bone marrow or the immune system. It consists of administration to the recipient a conditioning regimen including various combinations of chemotherapy, radiotherapy and immunotherapeutic agents which aims to destroy its immune system (to prevent transplant rejection) and, to a varying degree, malignant clone. Conditioning is followed by injection of the graft of hematopoietic stem cells. In this graft, the cells can recognize and destroy residual tumor cells of the recipient (graft effect against leukemia HVL). This reaction explains the interest of the allogeneic stem cell transplantation in hematological malignancies. Meanwhile, the immune system of the graft may cause deleterious reactions against recipient's organs that is the GVHD (graft against the host disease). HCT is associated with morbidity and mortality related to the toxicity of conditioning, GVHD and post-transplant immunosuppression. The incidence and severity of these complications depends on both parameters specific to the recipient (age, status of the blood disease) and the terms of the graft (type of packaging, HLA compatibility between the donor and the receiver, ex vivo manipulation of the graft, graft type). The development of new techniques and transplant procedures has improved the survival of transplanted patients and expand transplant indications. The main progress concerns the development of reduced conditioning, peripheral stem cell transplant or cord blood, and improved HLA typing techniques in unrelated transplants.

Keywords: Hematopietic stem cell ; Allogeneic;

Transplantation.

\section{RÉSUMÉ}

La greffe allogénique de cellules souches hématopoïétiques est un procédé potentiellement curatif dans une variété de maladies malignes et non malignes de la moelle osseuse ou du système immunitaire. Elle consiste en l'administration chez un receveur d'un régime de conditionnement incluant plusieurs combinaisons de radiothérapie et d'agents immunothérapeutiques dont le but est de détruire son système immunitaire (afin de prévenir la réaction de rejet) et du clone tumoral, à un moindre degré. Le conditionnement est suivi d'une injection du greffon de cellules souches hématopoḯtiques. Dans ce greffon, les cellules peuvent reconnaître et détruire les cellules tumorales résiduelles du receveur (effet du greffon contre la leucémie HVL). Cette réaction explique l'intérêt de la greffe de cellules souches mésenchymateuses dans les affections malignes. En même temps, le système immunitaire du greffon peut entrainer des effets délétères contre les organes du receveur qu'on appelle RGCH (réaction du greffon contre l'hôte). La HCT est associée à une morbidité et une mortalité en rapport avec le conditionnement, la RGCH et l'immunosuppression post-greffe. L'incidence et la sévérité de ces complications dépendent des deux paramètres spécifiques au receveur (âge, état de la maladie hématologique) et du greffon (type de conditionnement, compatibilité HLA entre le donneur et le receveur, manipulation ex vivo du greffon, type du greffon). Le développement de nouvelles technologies et de procédés de transplantation a amélioré la survie des patients transplantés et l'étendue des indications. Le progrès majeur concerne le développement d'un conditionnement réduit des greffons de cellules souches périphériques ou du cordon ombilical et l'amélioration des techniques de typage HLA chez les transplantés indépendantc.

Mots-clés : Cellules souches hématopoïétiques ; Allogéniques ; transplantation.

\section{Citation :}

Alem A, Bouamama F Brahimi M, Bekadja MA Allogeneic hematopietic stem cell transplantation. Batna J Med Sci 2017;4(1):90-7. https://doi.org/10.48087/ BJMStfa.2017.4118
الزرع الخيفي للخلايا الجذعية المكونة للام

الزرع الخيفي للخلايا الجذعية المكونة للدم هو إجراء علاجي لمجمو عة متنوعة من الأمر اض الخبيثة والغير الخبيثة في نخاع العظام أو الجهاز

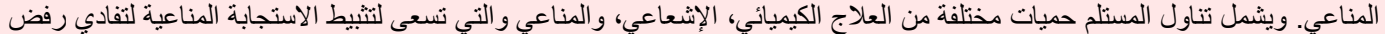

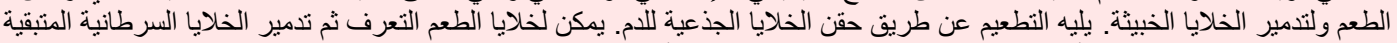

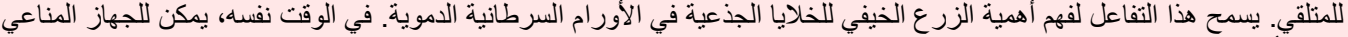

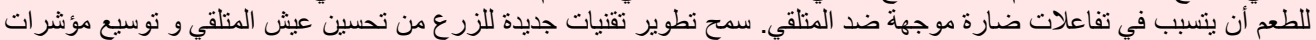

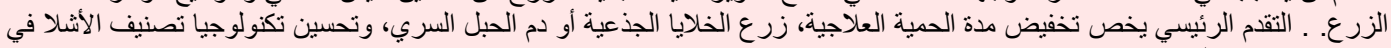
زرع غير ذات صلة. كلمات البحث: الخلايا الجذعية للام، غير الذات، الزرع. 


\section{INTRODUCTION}

The first hematopoietic stem cell transplantation (HSCT) was performed almost 50 years ago. HSCT is the process and intravenous infusion of hematopoietic stem and progenitor cells to restore normal hematopoiesis and/or treat malignancy; these include hematologic malignancies (eg, leukemia, lymphoma, and myeloma), nonmalignant acquired bone marrow disorders (eg, aplastic anemia), and genetic diseases associated with abnormal hematopoiesis and function (thalassemia, sickle cell anemia, and severe combined immunodeficiency). HSCT is also used in the support of patients undergoing high-dose chemotherapy for the treatment of some solid tumors), it is a process with an elevated rate of morbi-mortality, requiring specialized structures (sterile context, air filtering devices and many other equipments).

Hematopoietic stem cells are also characterized according to their source, either from the patient himself (autologous HSCT) or from another person, a so-called donor (allogeneic HSCT). In this article we focused our review on the second type of transplant.

\section{PRINCIPLES OF HSCT}

Stem cells used for HSCT are distinguished as being of hematopoietic origin, as there is growing interest in using more primitive stem cells for regenerative therapy due to their plasticity and unique biologic characteristics.

Autologous HSCT is used to pass through a hematopoietic failure during high dose chemotherapy for tumors of the hematopoietic system that are adequately sensitive to this treatment. In this sense autologous stem cell support is not a "trans-plant" but the term autologous HSCT is commonly used. Results of both of these procedures are often reported together as they use similar technology [1]

Allogeneic HSCT which is a potentially curative procedure is used to replace the hematopoietic system in patients with acquired or congenital failure, and more commonly to exploit the graft versus tumor effect of allogeneic cells [2]. According to the European Group for Blood and Marrow Transplantation 2010 annual survey, 33,362 transplants were performed. Among these later, 13,345 were allogeneic and 20,017 autologous [3]. Figure 1 shows the evolution of the number of transplants, which is in a continuous increase from 1990 to 2010 [3].

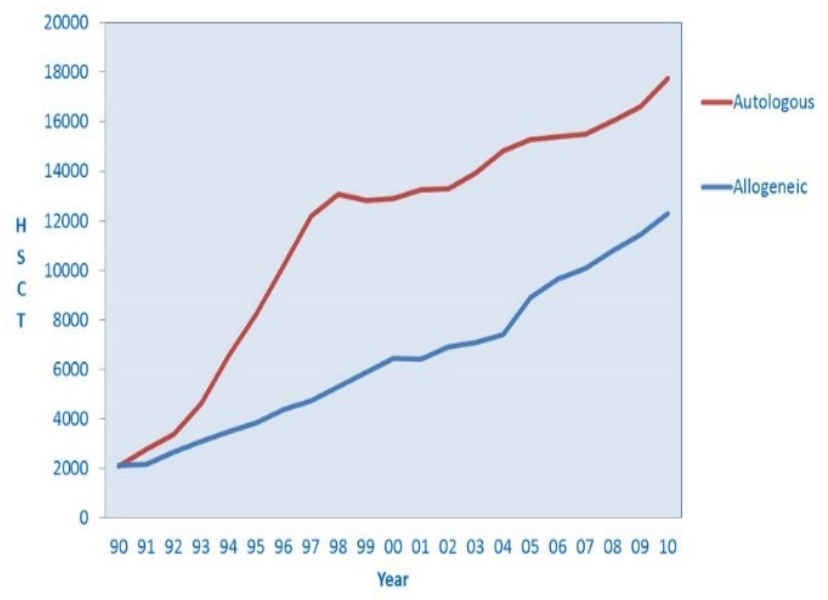

Figure 1. Autologous and Allogeneic HSCT in Europe (1990-2010)
The primary biologic objectives of HSCT for malignant diseases and marrow disorders include the following: 1) Delivery of chemotherapy/radiotherapy sufficient to destroy tumor cells; 2) Infusion of a source of hematopoietic stem cells to replace damaged lymphoid or myeloid progenitors; 3 ) Establishment of organ graft tolerance to prevent rejection of donor cells; 4) Induction of graft-versus-tumor (GVT) activity by allogeneic immune effectors cells. Figure 2 gives an overview of the process for allogeneic HSCT.

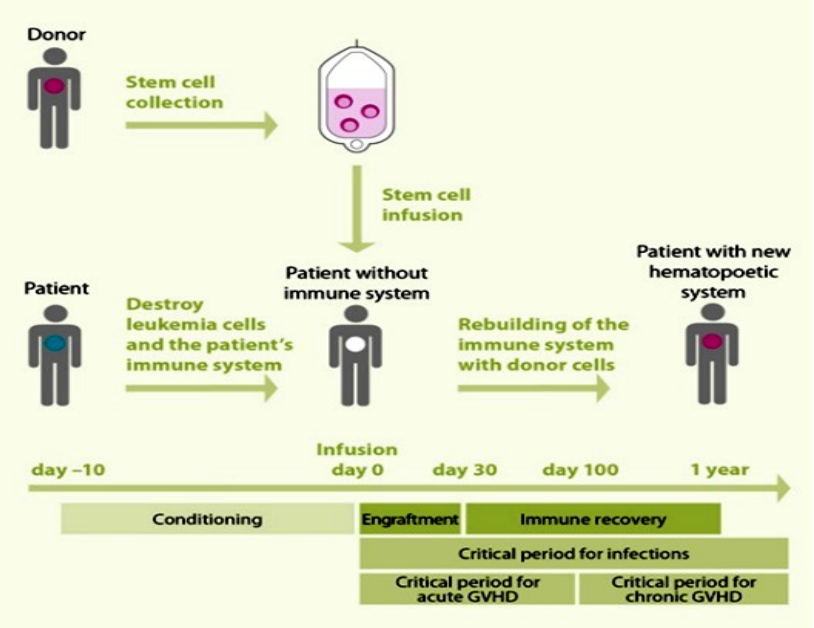

Figure 2. Principle of allogeneic HSCT

\section{CLINICAL INDICATIONS FOR ALLOGENEIC HSCT}

The most common use of allogeneic HCT has been for the eradication of hematologic malignancies, such as leukemia and non-Hodgkin lymphoma. HSCT is associated with significant toxicity and mortality risks (in particular with allogeneic HSCT). Thus, the important step is to consider the prognosis of the patient if HSCT is not performed, and assess whether the benefit of HSCT (reduction of relapse risk) significantly outweighs its toxicity and upfront mortality risks.

The vast majority of allogeneic HSCT (70\%) are done for hematologic malignancies, in particular: acute myeloid leukemia (AML, 32\%) and acute lymphoblastic leukemia (ALL $16 \%$ ), myelodysplastic syndromes (MDS 16\%) and nonHodgkin lymphoma (NHL) (9\%) [4]. Beside these frequent indications, these are a host of less frequent indications including many malignant and non-malignant diseases (figure 3 and table 1).

\section{Acute myelogenous leukemia (AML)}

The most common indication for allogeneic HSCT is AML, this procedure improved the disease-free survival in patients with intermediate and high risk disease in first complete remission (CR1) but not in patients with low risk disease, as smaller benefits in relapse reduction are offset by increased treatment related morbidity and mortality [5]

\section{Acute lymphoblastic leukemia (ALL)}

Allogeneic HSCT is indicated in patients with ALL in early stage of the disease and if the patient presents with high-risk features. All other patients undergo allogeneic HSCT only after relapse and reinduction [6]. 


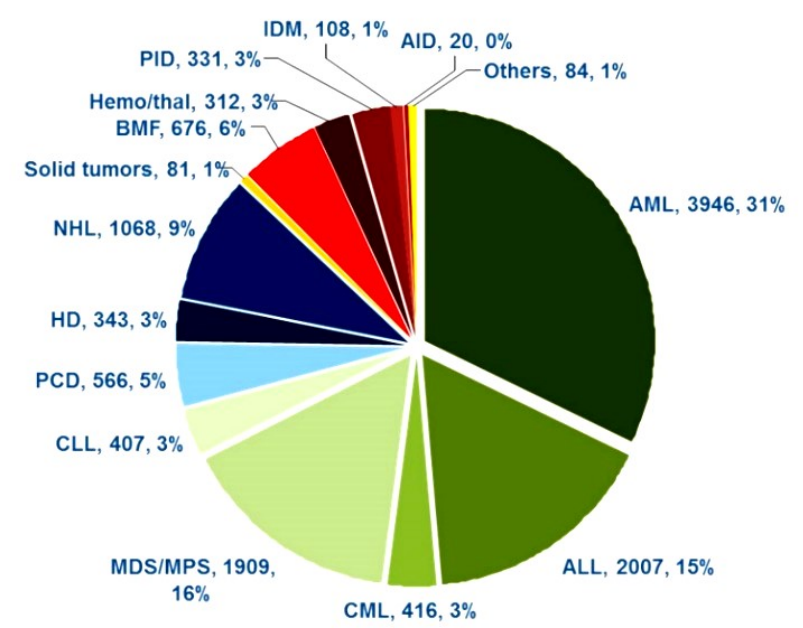

Figure 3. Indications for allogeneic HSCT in Europe in 2010 [3]. Abbreviations: AML Acute Myeloid Leukemia, ALL Acute Lymphoblastic Leukaemia, CML Chronic Myeloid Leukaemia; MDS/MPS Myelodysplastic Syndromes/Myeloproliferative Neoplasias, CLL Chronic Lymphocytic Leukemia, PCD plasma cell disorders, HD Hodgkin Lymphoma, NHL Non Hodgkin Lymphoma, Hemo/thal Hemoglobinopathies/Thalassemias, BMF Bone Marrow Failure, PID Primary Immunodeficiencies, IDM Inborn Errors of Metabolism, AID Autoimmune Disorders.

\section{Myelodysplastic syndrome (MDS)}

Allogeneic HSCT is the only potentially curative option for MDS. However, the natural course and prognosis of MDS varies widely and the optimal timing of HSCT is difficult to determine, particularly with recent availability of hypomethylating agents. The decision needs to consider several factors, such as patient age; comorbid conditions; International Prognostic Scoring System (IPSS) or World Health Organization Classification-Based Prognostic Scoring System score; psychosocial status, including the availability of a caregiver; and the availability of a donor.

Table 1. Common indications of allogeineic HSCT

\begin{tabular}{l}
\hline \multicolumn{1}{c}{ Malignancies } \\
\hline Acute myeloid leukaemia \\
Acute lymphoblastic leukaemia \\
Chronic myeloid leukaemia (refractory to tyrosine kinase \\
inhibitors) \\
Myelodysplastic syndromes (high risk) \\
Myeloproliferative neoplasia (high risk) \\
Non Hodgkin lymphoma \\
Hodgkin lymphoma \\
Plasma cell myeloma \\
Chronic lymphocytic leukaemia \\
\hline \multicolumn{1}{c}{ Non malignant disorders } \\
\hline Acquired Severe aplastic anaemia \\
Paroxysmal nocturnal hemoglobinuria (not \\
eligible for complement inhibition treatment) \\
Fanconi anaemia and other marrow failure \\
syndromes \\
Thalassemia \\
Sickle cell disease \\
Congenital immunodeficiency syndromes \\
Inborn errors of metabolism
\end{tabular}

\section{Aplastic anemia (AA)}

HSCT in severe AA is standard of care for young patients below the age of 40 to 50 years. Older patients are usually transplanted after having failed immunosuppressive treatment, which may also result in hematopoietic reconstitution; patients without sibling donors will receive transplants from alternative donors if failing immunosuppression.

\section{Chronic myelogenous leukemia (CML)}

Over the past decade, the indications for HSCT in CML have completely changed as a result of the development of tyrosine kinase inhibitors (TKIs). Three TKIs (Imatinib, Dasatinib, Nilotinib) are currently available. Allogeneic HSCT is considered for patients with a history of blast crisis (second or subsequent chronic phase) or after blast crisis. It is considered as salvage therapy for patients with accelerated phase and chronic phase after failing to achieve hematologic/cytogenetic response to TKIs.

\section{Chronic Lymphocytic Leukemia (CLL)}

Allogeneic HSCT can be considered for some few patients in whom one or more standard courses of treatment, including fludarabine/rituximab-containing regimens with high-risk features (short duration of response, ZAP70+, CD38+, chromosome $17 \mathrm{p}$ deletion), have failed.

\section{Myelofibrosis / Myeloproliferative Disorders}

Allogeneic HCT is the only potentially curative therapy for myelofibrosis/myeloproliferative disorders. But because of the heterogeneity in their prognosis and natural course, it is very important to select only high-risk patients for this kind of therapy.

\section{Non-Hodgkin Lymphoma (NHL)}

Autologous HSCT is the treatment of choice for patients with relapsed or refractory diffuse large B-cell NHL that responded to salvage therapy.

Allogeneic HSCT can be considered for patients with: 1) relapsed, 2) induction failure; 3) intermediate- or high-grade NHL who could not proceed with auto-HCT because of bone marrow involvement of lymphoma or failure to collect a sufficient number of CD34+ hematopoietic progenitor cells, 4) patients who relapsed after prior autologous HCT, 5) and in whom secondary MDS developed.

\section{Hodgkin Lymphoma}

Reduced-intensity allogeneic HSCT can be considered for Hodgkin lymphoma patients who relapsed after autologous HSCT.

\section{Multiple Myeloma}

Autologous HSCT is associated with high response rates and remains the standard of care for patients with multiple myeloma after initial induction therapy, but it's not considered curative. Currently allogeneic HSCT is reserved for very high-risk patients in first remission, or for patients relapsing early after first line treatment [7] 


\section{TECHNIQUES}

\section{Choice of the donor according to HLA typing}

The HLA typing is performed for the patient and his family (Allele typing for A, B, C, DRB1, DQB1, and DPB1). The donor can be: 1) HLA identical sibling, 2) unmatched unrelated donor (MUD), 3) haploidentical family peripheral blood stem cell (PBSC) or bone marrow donor, or 4) HLA-mismatched unrelated cord blood (UCB) donor [8]. Once a donor is found a pre-transplantation analysis are done: blood group, $\mathrm{CBC}$, hemoglobin electrophoresis, serologies (VIH HBV, HCV , CMV, toxoplasmosis and syphilis ), thyroid hormones, cardiac and respiratory assessment, and B-HCG if the donor is a women.

\section{Choice of stem cell source}

The source and the acquirement of the hematopoietic stem cells (HSC) has varied and diversified over time. Nowadays, there are three possibilities: 1- Bone marrow (BM) HSC, 2Granulocyte-colony stimulating factors (GCSF) mobilized peripheral blood HSC, 3- And Cord blood (CB).

Traditionally, HSC were harvested from the iliac crests under general anesthesia. Thereafter, mobilized PBSC have been increasingly used in both auto-and allo- HSCT. Mobilization of HSC in sufficient number in peripheral blood can be achieved by the classical administration of growth factor such as G-CSF (allogeneic HSCT) and /or myelosuppressive chemotherapy (auto-HSCT). In the 1990s, unmanipulated CB cells collected and cryopreserved at birth has been used both in related and unrelated HLA matched and mismatched allogeneic transplants in children, and more recently in adults.

According to the European bone marrow transplant, in 2005, the stem cell source for auto-HSCT was from peripheral blood in $98 \%$. In the allogeneic setting, BM was used in $20 \%$ of transplants and PBSC in 74\%. [9]. Table 2 shows the characteristic of each stem cells source.

Table 2. Main characteristics of each stem cells source.

\begin{tabular}{|c|c|}
\hline $\begin{array}{l}\text { Stem Cells } \\
\text { Source }\end{array}$ & Characteristics \\
\hline $\begin{array}{l}\text { BONE } \\
\text { MARROW }\end{array}$ & $\begin{array}{l}\text { Collection under general anesthesia } \\
\text { Limited number of hematopoietic stem cells } \\
\text { Median number of nucleated cells: } 2^{*} 10^{8} / \mathrm{Kg} \\
\text { Median number of CD } 34+\text { cells: } 2,8^{*} 10^{6} / \mathrm{Kg} \\
\text { Median number of T cells: } 2,2^{*} 10^{7} / \mathrm{Kg}\end{array}$ \\
\hline $\begin{array}{l}\text { G-CSF } \\
\text { mobilized } \\
\text { PBSC }\end{array}$ & $\begin{array}{l}\text { Collection easy } \\
\text { No requirement for general anesthesia } \\
\text { Side effects of G-CSF } \\
\text { High number of cells } \\
\text { Median number of nucleated cells: } 9^{*} 10^{8} / \mathrm{Kg} \\
\text { Median number of CD34+ cells }: 7^{*} 10^{6} / \mathrm{Kg} \\
\text { Median number of T cells }: 27^{*} 10^{7} / \mathrm{Kg}\end{array}$ \\
\hline $\begin{array}{l}\text { CORD } \\
\text { BLOOD }\end{array}$ & $\begin{array}{l}\text { Collection easy and harmless } \\
\text { Immediate availability of cryopreserved nits and } \\
\text { lower risk of transmissible diseases } \\
\text { Acceptable partial HLA mismatches } \\
\text { Median number of nucleated cells: } 0.3^{*} 10^{8} / \mathrm{Kg} \\
\text { Median number of CD34+ cells }: 0.2^{*} 10^{6} / \mathrm{Kg} \\
\text { Median number of T cells }: 0.4^{*} 10^{7} / \mathrm{Kg}\end{array}$ \\
\hline
\end{tabular}

\section{Stem cell manipulation}

Characterization of the stem cell phenotype has allowed the development of strategies by which PBSC grafts can be manipulated ex vivo. By using CD34-specific antibodies conjugated with magnetic beads, highly efficient enrichment of CD34+ cells can be achieved. This technology also allows, as a consequence of passive depletion of CD34- cells, efficient depletion of contaminating donor $\mathrm{T}$ cells in allogeneic stem cell harvests. It is worthy to keep in mind that this kind of manipulations is rarely performed.

\section{Conditioning regimens}

Conditioning regimens vary in intensity and are categorized by the duration of cytopenia and on the requirement for stem cell support. There are three levels of intensity: 1) nonmyloablative (NMA), 2) reduced-intensity conditioning (RIC), and 3) high-intensity or myeloablative conditioning (MAC).

MAC regimens cause irreversible cytopenia and require stem cell support. In addition, the transplanted immune system can recognize mismatched minor histocompatibility antigens or tumor antigens expressed on tumor cells. The resulting anticancer effect is called the graft-versus-malignancy effect (this is commonly referred to as graft-versus-leukemia or graft-versus-lymphoma GVL).

Thus, a myeloablative transplant is two-pronged attack on the underlying disease and has a lower relapse rate. Unfortunately, the dose intensity of the conditioning may be prohibitively toxic for older patients or for patients with comorbid diseases and early transplantation mortality can be substantial. Moreover, dose intensity may predispose to more severe early GVHD.

Typically, preparative regimens for full allogeneic HSCT consist of total body irradiation and/or chemotherapeutic agents (cyclophosphamide, busulfan, and etoposide). The most commonly used regimens are (1) total body irradiation (Several schemes are used, the total dose being usually of the order of $12 \mathrm{~Gy}$, most often delivered in six fractions of 2 Gy 3 Day) and cyclophosphamide (60 mg/kg for 2 days); (2) fractionated total body irradiation and etoposide $(60 \mathrm{mg} / \mathrm{kg})$; and (3) busulfan (16 mg/kg over 4 days) and cyclophosphamide (60 mg/kg for 2 days) [10].

The recognition of the contribution of GVL activity to disease eradication led to the development of NMA and RIC stem cell transplantation. NMA regimens cause minimal cytopenia and can be given without stem cell support if required. RIC regimens are intermediate between MAC and NMA because they cause cytopenias of variable duration and should be given with stem cell support. Cytopenia may or may not be reversible. Both conditioning regimens are used for older patients or those who are not eligible for myeloablative regimens (usually due to age, comorbidities, or receipt of prior autologous transplantation). These transplants are designed not to have direct antitumor activity, but rather to provide sufficient host immunosuppression to permit engraftment of donor hematopoietic and lymphoid effectors cells. These effect cells can mediate a GVL effect responsible for tumor control. This type of transplantation is most appropriate either for diseases in remission (e.g., AML in complete remission) or for diseases that tend to be more indolent (e.g., CCL)

These approaches use lower doses of chemotherapy, with or without total body irradiation and immunosuppression, the most common regimens use fludarabine combined with either melphalan, busulfan or with a single fraction of total body irradiation, followed by infusion of either donor bone marrow or peripheral blood-derived stem cells. 


\section{Transplant Phase}

After completion of the preparative regimen, there is a day or more wait before reinfusion of marrow or peripheral blood stem cells. This delay allows for elimination of any active drug metabolites so that the reinfused cells are not injured by any remaining drug. Minimal toxicities are associated with the infusion. They include headache, nausea, and dizziness.

\section{Management of aplasia}

Aplasia phase that lasts between 15 and 30 days depending on conditioning regimens, the patient must be kept in a sterile room with compliance with strict rules because of infection risks, transfusion support, monitoring and treatment GVHD. Infectious fever should be treated with antibiotic, anti-viral or anti-fungal

\section{EARLY COMPLICATIONS (DAY 0-90):}

\section{Primary graft failure}

By definition, it is a failure to achieve a neutrophil count above $0.5 \times 10^{9} / \mathrm{L}$ within 28 days of stem cell infusion, and most commonly occurs as a consequence of graft rejection. It is rare except in the setting of T-cell depletion or where there is marked donor-host HLA disparity, such as that seen using a mismatched unrelated or family donor; patients are candidates for urgent intervention in the form of a second transplant from the same donor or an infusion of cryopreserved autologous stem cells. The mortality of primary graft failure is in excess of $50 \%$ [11].

\section{Acute graft-versus-host disease (aGVHD)}

GVHD remains, directly or indirectly, the major cause of short-term mortality after allogeneic HSCT (before day 100)[12]. The pathology of aGvHD has been attributed to a three phase process including: 1) initial tissue damage from the conditioning regimen which in turn leads to activation of host antigen-presenting cells, 2) activation and proliferation of donor T-cells (afferent phase) and 3) finally to the release of inflammatory cytokines such as interleukin-1 and tissue necrosis factor (TNF)- $\alpha$ that eventually produce tissue necrosis (efferent phase).

The syndrome usually occurs in the first hundred days after HSCT but late onset aGvHD may occur particularly after reduced intensity conditioning HSCT and can vary in severity. Table 3 shows a commonly used grading system for GVHD. This system has both therapeutic and prognostic importance.

Grade III-IV aGvHD has an extremely poor prognosis despite therapeutic intervention and consequently considerable efforts are made to try and prevent its occurrence; for prophylaxis, patients receive immunosuppressive drugs, most commonly a combination of cyclosporine and methotrexate or mycophenolic acid. In contrast to organ transplantation, this prophylaxis can be tapered off and stopped in patients not developing GVHD after 6 to 12 months [13].

\section{Infectious complications}

Infections remain a main cause of morbidity and mortality in patients undergoing HSCT [14]. The major risk factors for
Table 3. Clinical classification of aGVHD according to organ injury [12]

\begin{tabular}{|c|c|c|c|c|c|c|c|}
\hline Stage key & 0 & \multicolumn{2}{|c|}{1} & \multicolumn{2}{|l|}{2} & 3 & 4 \\
\hline Skin & Norash & \multicolumn{2}{|c|}{$\begin{array}{l}\text { Maculopasular rash, } \\
\text { less than } 25 \% \text { of boody } \\
\text { surface }\end{array}$} & \multicolumn{2}{|c|}{$\begin{array}{l}\text { Maculopapular rash, } \\
25 \%-50 \% \text { of tooty } \\
\text { surface }\end{array}$} & $\begin{array}{l}\text { Rash on yleater than } \\
50 \text { of of body surtace } \\
\text { or generalalized } \\
\text { enythroderma }\end{array}$ & $\begin{array}{l}\text { Generealleed } \\
\text { or entrucoderma } \\
\text { with bullous } \\
\text { formation and/or } \\
\text { desquamation }\end{array}$ \\
\hline $\begin{array}{l}\text { Lower GI } \\
\text { (diarnea) }\end{array}$ & $\begin{array}{l}<500 \mathrm{~m} / \mathrm{dor} \\
<280 \mathrm{~m} / \mathrm{m}^{2}\end{array}$ & \multicolumn{2}{|c|}{$\begin{array}{l}>500 \text { but } \\
\leqslant 1,000 \mathrm{~mL} / \mathrm{dor} \\
280-555 \mathrm{~mL} / \mathrm{m}^{2}\end{array}$} & \multicolumn{2}{|c|}{$\begin{array}{l}>1,000 \text { but } \\
s 1,500 \mathrm{~mL} / \mathrm{dor} \\
556-833 \mathrm{~mL} / \mathrm{m}^{2}\end{array}$} & $\begin{array}{l}>1.500 \mathrm{~m} / \mathrm{d} \mathrm{dor} \\
>833 \mathrm{~m} / \mathrm{m}^{2}\end{array}$ & $\begin{array}{l}\text { Severe abdominal } \\
\text { pain with or without } \\
\text { ileus or stool with } \\
\text { frank blood or melena }\end{array}$ \\
\hline Upper $G$ l & $\begin{array}{l}\text { No protoracted navsea } \\
\text { and vomiting }\end{array}$ & \multicolumn{4}{|c|}{$\begin{array}{l}\text { Persistent nausea, vomiting, } \\
\text { or anorexia plus bloossy showing } \\
\text { GHHD of the stomach or } \\
\text { duoderum }\end{array}$} & & \\
\hline $\begin{array}{l}\text { Liver } \\
\text { (totat bilinvin) }\end{array}$ & $<2.0 \mathrm{~m} / \mathrm{dll}$ & \multicolumn{2}{|c|}{$2.0-3.0 \mathrm{~m}$ m/d } & \multicolumn{2}{|l|}{$3.1-6.0 \mathrm{mg} / \mathrm{ol}$} & $6.1-15.0 \mathrm{~m} / \mathrm{dl}$ & $>15 \mathrm{mg} / \mathrm{ll}$ \\
\hline \multicolumn{8}{|c|}{ Overall clilical gradihg of severtity of acute GYHD-1994 Keystone Consensus Citterla } \\
\hline Grade & Skin & & Uver & & out & KPS & \\
\hline 1 & $1-2$ & $\&$ & 0 & $\&$ & 0 & & \\
\hline$\|$ & 3 & a & 1 & a & 1 & & \\
\hline III & $0-4$ & a & $2-3$ & $\alpha$ & $2-4$ & & \\
\hline IV & 4 & or & 4 & a & $0-4$ & $\begin{array}{l}\text { KPS } \\
\text { base }\end{array}$ & $\begin{array}{l}30 \text { or deccease } 240 \text { from } \\
\text { scove }\end{array}$ \\
\hline
\end{tabular}

infections after HSCT are 1) the status of the hematological disease at HSCT, 2) the co-morbidities of the patient, 3) the degree of neutropenia, 4) the disruption of anatomical barriers (mucositis and indwelling catheters), 5) depressed T- and B-cell function and 6) immunosuppressive therapy. The peak incidence of infections changes in distinct phases: bacterial infections being most common in the early phase during marrow aplasia, fungal and viral infections may appear early and later in the post-transplant phase. The most common viral infections are with viruses that remain in a latency phase belonging to the herpes family. Of these the cytomegalovirus is most commonly reactivated and there is a relationship between viral infections and GVHD, as viral infections may trigger GVHD events and immunosuppressants used to treat GVHD favour viral replication (figure 4).

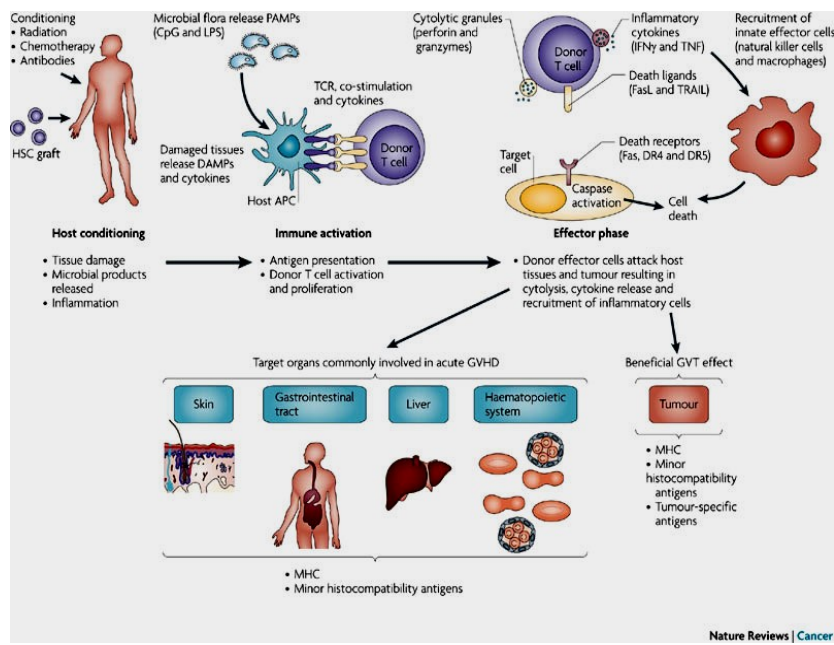

Figure 4. Pathophysiology of acute GVHD and GVT effects.

\section{Organ toxicity}

The acute toxicities of irradiation and chemotherapy include nausea and vomiting, which can be managed by prophylactic use of antiemetics, particularly serotonin antagonists. Busulfan can cause seizures; prophylactic phenytoin is 
effective in preventing this complication. Both cyclophosphamide and Etoposide require forced hydration to reduce toxicities. Table 4 lists the acute and long-term toxicities of the major agents used in HSCT preparative regimens. Hemorrhagic cystitis is one of serious complications of HSCT and causes significant morbidity, prolongation of hospitalization, and, occasionally, death. Various additional complications have been described in patients with hemorrhagic cystitis such as obstructive uropathy, hydronephrosis, tubule interstitial nephritis, acute renal failure and bladder perforation.

\begin{tabular}{|c|c|c|}
\hline Agent & Acute toxicity & Long-term toxicity \\
\hline Total-body irradiation & $\begin{array}{l}\text { Nausea, vomiting, enteritis, } \\
\text { mucositis }\end{array}$ & $\begin{array}{l}\text { Cataracts, sterility, } \\
\text { pneumonitis, } \\
\text { myelodysplasia }\end{array}$ \\
\hline Cyclophosphamide & $\begin{array}{l}\text { Nausea, vomiting, hemorrhagic } \\
\text { cystitis, cardiac toxicity }\end{array}$ & Sterility, leukemia \\
\hline Etoposide & $\begin{array}{l}\text { Skin rash, hypotension, } \\
\text { acidosis, mucositis }\end{array}$ & Leukemia \\
\hline Carmustine & $\begin{array}{l}\text { Seizures, nausea, vomiting, } \\
\text { headaches }\end{array}$ & $\begin{array}{l}\text { Interstitial } \\
\text { pneumonitis }\end{array}$ \\
\hline Busulfan & $\begin{array}{l}\text { Seizures, nausea, vomiting, } \\
\text { veno-occlusive disease }\end{array}$ & $\begin{array}{l}\text { Alopecia, pulmonary } \\
\text { fibrosis }\end{array}$ \\
\hline Cisplatin & $\begin{array}{l}\text { Renal impairment, } \\
\text { hearing loss, tinnitus }\end{array}$ & $\begin{array}{l}\text { Hearing loss, tinnitus, } \\
\text { neuropathy }\end{array}$ \\
\hline Thiotepa & $\begin{array}{l}\text { Nausea, vomiting, CNS changes, } \\
\text { veno-occlusive disease }\end{array}$ & - \\
\hline Paclitaxel & Allergic reactions & Neuropathy \\
\hline Fludarabine & $\begin{array}{l}\text { Hemolytic anemia, } \\
\text { CNS changes }\end{array}$ & $\begin{array}{l}\text { Prolonged immune } \\
\text { suppression, EBV related } \\
\text { lympho-proliferative } \\
\text { disorder }\end{array}$ \\
\hline Melphalan & Nausea, pulmonary toxicity & Peripheral neuropathy \\
\hline
\end{tabular}

CNS - central nervous system; EBV - Epstein-Barr virus

Table 4. Acute and long-term toxicities of common preparative agents used for allogeneic HSCT [12].

\section{Complications of endothelial origin}

There are a number of complications where injury to the vascular endothelium seems to be the most important initial event. These have imprecise diagnostic criteria and overlapping clinical features and are observed within the first 30-60 days after HSCT. The best-defined syndromes resulting from this endothelial injury are: 1) veno- occlusive disease of the liver; 2) Capillary leakage syndrome; 3) engraftment syndrome; 4) diffuse alveolar hemorrhage; 5) HSCTassociated thrombotic microangiopathy; 6) idiopathic pneumonia syndrome (IPS) is the consequence of noninfectious lung injury after HSCT caused by the toxic effects of conditioning, immunological cell-mediated injury, inflammatory cytokines, flora-derived LPS and - probably occult pulmonary infections.

\section{LATE COMPLICATIONS OF ALLOGENEIC HSCT}

As the results of allogeneic HSCT have improved, its longterm complications have come to be better recognized and represent an increasingly important cause of morbidity in patients who might otherwise be considered to be cured of their underlying disease. Among these late complications we can cite:

\section{Chronic graft-versus-host disease (cGVHD)}

cGVHD is an immunoregulatory disorder occurring after allogeneic HSCT and shares features of autoimmunity and immunodeficiency. Features of cGVHD looks like other autoimmune diseases such as Sjögren syndrome, scleroderma, primary biliary cirrhosis and immuncytopenias. Similarly to aGVHD, cGVHD is also thought to be induced by the immune cells of the donor but the pathophysiology is even less well understood. Although auto reactive Tlymphocytes are considered to play the key role, recent data revealed the importance of B-cells. cGVHD is the main cause of late non-relapse mortality and morbidity after allogeneic HSCT. Mortality is primarily caused by infections either due to the immunodeficiency of cGVHD or its treatment [14-15]. The major risk factors for the development of cGVHD are prior aGVHD: 1) higher degree of HLA mismatch, 2) older patient age, 3) previous splenectomy, 4) CMV seropositivity, 5) female donor to male recipient and 5) mobilized peripheral blood stem cell graft.

The diagnosis of cGvHD is based on its clinical manifestations. The signs and symptoms of cGVHD may occur in any organ but the most frequently affected organs/sites are the skin, nails, mouth, eyes, female genitalia, gastrointestinal tract, liver, lungs, muscles, fascia and joints (figure 5). The disease may be mono-symptomatic, but can also be widespread and leading to debilitating consequences such as end stage lung disease or joint contractures.

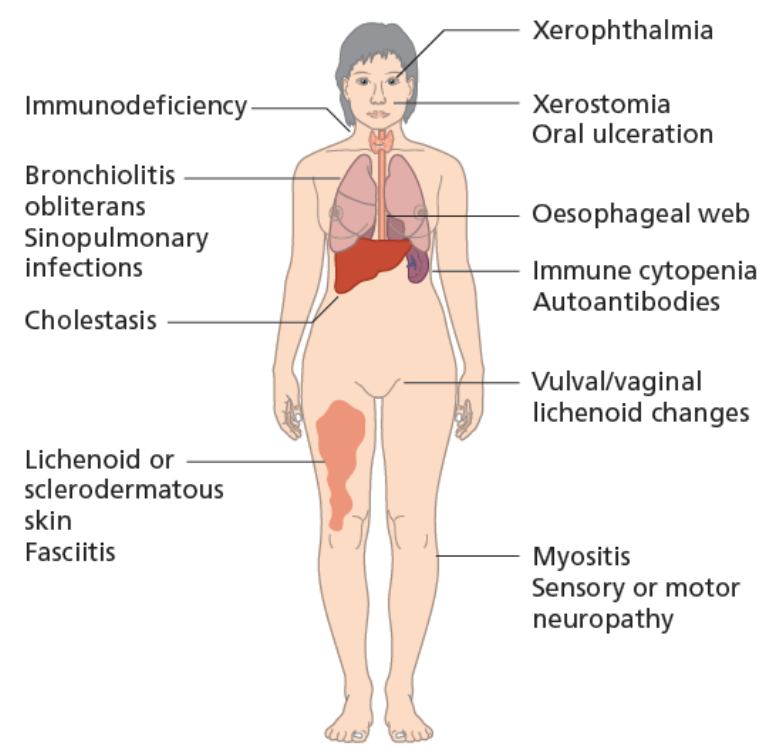

Figure 5. Clinical manifestations of chronic GVHD [11].

Limited disease necessitates only local treatment, and this avoids further immunosuppression which might result in infectious complications and the other side effects of long term steroids. In the case of extensive disease systemic treatment is necessary and patience and appropriate evaluation of response is very important. Most patients require immunosuppressive treatment for up to 1 year, with more than half of them still on therapy after 2 years. Treatment is orally administered prednisolone, cyclosporin (CsA) with the dose of CSA adjusted to plasma levels and other immune-suppressive drug and symptomatic treatment [14].

\section{Secondary malignancies}

The incidence of solid tumors in recipients of allogeneic HSCT is increased compared with control populations and includes 
a higher rate of skin or buccal cavity squamous cell carcinoma and melanoma. In the largest study to date, the cumulative incidence of all solid tumors was $2.2 \%$ at 10 years and $6.7 \%$ at 15 years [16]. Risk factors for the development of secondary malignancies include the use of total body irridiation in the conditioning regimen and the presence of cGVHD. Post-transplant lymphoproliferative disorder (PTLD) includes a spectrum of Epstein-Barr virus (EBV)-driven Bcell hyperproliferative states that range from polyclonal benign proliferations to threatening neoplastic disease [17]

\section{Growth, puberty, fertility and other endocrine dysfunctions}

Retarded growth is seen predominantly in children who have received irradiation, particularly cranial irradiation. Growth retardation is multifactorial and, although growth hormone levels may be diminished as a consequence of hypothalamic or pituitary irradiation, this does not entirely account for the observed reduction in height. Gonadal failure (both testicular and ovarian) is a common consequence of myeloablative conditioning regimens, particularly those that contain total body irradiation or busulphan [18]. To preserve their fertility, young patients can choose to store their gametes or germinal tissues (testes, ovaries) by cryopreservation. Hypothyroidism, osteoporosis and avascular necrosis can be included among the late complications.

\section{OUTCOMES OF ALLOGENEIC HSCT}

The outcomes of allogeneic HSCT are very encouraging, they depend on: 1) patients factors (e.g. age and comorbidities); 2) disease factors: (e.g. diagnosis, disease stage, and prior therapy); 3) donor factors: (HLA and gender match), and 4) transplantation factors: (including conditioning regimen, stem cell source, and GVHD prophylaxis). Table 5 lists estimates of long term survival for some of the hematologic malignancies and marrow disorders for which transplantation is commonly performed [10].

Table 5. Outcomes of some of the hematologic malignancies and marrow disorders [10].

\begin{tabular}{ll}
\hline Disease & Approximate 5-year DFS (\%) \\
\hline AML/ALL & $25-751^{\text {st }}$ complete remission (CR1) \\
& $20-402^{\text {nd }}$ complete remission (CR2) \\
& 5-20 Refractory \\
CML & 50-80 Stable phase \\
& 20-40 Accelerated phase \\
& 5-15 Blastic crisis \\
NHL/HD/CLL & 20-60 Chemo sensitive relapse \\
& 10-25 Refractory disease \\
MDS & 50-65 Refractory anemia with and without \\
& sideroblastes \\
Multiple myeloma & $10-35$ refractory anemia with blast excess \\
Aplasic anemia & $40-85$ \\
\hline
\end{tabular}

\section{CONCLUSION}

At present, hematopoietic stem-cell transplantation provides the best chance to cure many diseases. More research efforts are done in order to determine the best ablative regimens for specific conditions, and technical advances must be accomplished to improve the effectiveness of reducedintensity regimens. The use of cytokine antagonists, suicide genes and the infusion of regulatory $\mathrm{T}$ cells may reduce the severity of GVHD, and give a better understanding of the genetic polymorphisms involved in its development may also help prevent the disease.

Also the progress must be made in donor selection. More knowledge will be available to include information on polymorphisms in the HLA and non-HLA regions to define lower risk donors for particular patients. Supportive care will benefit as it has in the past from better antiviral and antifungal drugs.

Competing interests: The authors declare that they have no financial or personal relationships that may have inappropriately influenced them in writing this article.

\section{REFERENCES}

1. Copelan EA. Hematopoietic stem-cell transplantation. N Engl J Med. 2006; 354(17):1813-26.

2. Gyurkocza B, Rezvani A, Storb RF. Allogeneic hematopoietic cell transplantation: the state of the art. Expert Rev Hematol. 2010 3(3):285-99.

3. Passweg JR et al. The EBMT activity survey: 1990-2010. Bone marrow transplantation. 2012; 47(7): 906-923.

4. Koreth J et al. Allogeneic stem cell transplantation for acute myeloid leukemia in first complete remission: a systematic review and metaanalysis of prospective clinical trials. JAMA. 2009; 301(22):2349-60.

5. Döhner $\mathrm{H}$ et al. Diagnosis and management of acute myeloid leukemia in adults: recommendations from an international expert panel, on behalf of the European LeukemiaNet. Blood. 2010; 115:453-474

6. Frassoni F. HSCT for lymphoblastic leukemia in adults. In: The EBMT Handbook 5th edition 2008.

7. Sanz $\mathrm{G}$ et al. Hematopoietic stem cell transplantation. In: The EBMT handbook 5th edition 2008.

8. Gluckman E. Choice of the donor according to HLA typing and stem cell source. Haemotopoietic Stem cell transplantation. EBMT Handbook. 2012; 6, 90-107.

9. Larghero J, Garcia J, Gluckman E. Sources and procurement of stem cells, Hematopoietic stem cell transplantation The EBMT Handbook 2008 revised edition

10. Antin JH and Raley DY. Manual of stem cell and bone marrow transplantation. Cambridge University Press, 2013.

11. Craddock C and Chakraverty R. Stem cell transplantation. In: Postgraduate Hematology Fifth edition. 2005.

12. Forman SJ, Blume KG, Thomas ED. (Eds.). Hematopoietic cell transplantation. Blackwell Science. 1999.

13. Martin PJ et al. First and second-line systemic treatment of acute graft-versus-host disease: recommendations of the American Society of Blood and Marrow Transplantation. Biol Blood Marrow Transplant. $2012 ; 18(8), 1150-1163$.

14. Rovira M, Mensa J, Carreras E. Infections after HSCT. EBMT Handbook 2012. 


\section{MONOGRAPHIE}

15. Pavletic SZ et al. Chronic graft-versus-host disease: implications of the National Institutes of Health consensus development project on criteria for clinical trials. Biology of Blood and Marrow Transplantation. 2006 ; 12(3), 252-266.

16. Curtis RE et al. Solid Cancers after Bone Marrow Transplantation N Engl J Med 1997; 336(13), 897-904.
17. Baker KS et al. New malignancies after blood or marrow stem-cell transplantation in children and adults: incidence and risk factors. JCO. 2003; 21(7), 1352-1358.

18. Socie $\mathrm{G}$ et al. Nonmalignant late effects after allogeneic stem cell transplantation. Blood 2003; 101(9), 3373-3385.

Cet article a été publié dans le « Batna Journal of Medical Sciences » BJMS, I'organe officiel de " l'association de la Recherche Pharmaceutique - Batna»

Le contenu de la Revue est ouvert « Open Access » et permet au lecteur de télécharger, d'utiliser le contenu dans un but personnel ou d'enseignement, sans demander l'autorisation de l'éditeur/auteur.

Avantages à publier dans BJMS :

- Open access : une fois publié, votre article est disponible gratuitement au téléchargement

Soumission gratuite : pas de frais de soumission, contrairement à la plupart des revues « Open Access »

Possibilité de publier dans 3 langues : français, anglais, arabe

- Qualité de la relecture : des relecteurs/reviewers indépendants géographiquement, respectant l'anonymat, pour garantir la neutralité et la qualité des manuscrits.

Pour plus d'informations, contacter BatnaJMS@gmail.com

ou connectez-vous sur le site de la revue : www.batnajms.com

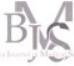

Batna Journal of

Medical Sciences

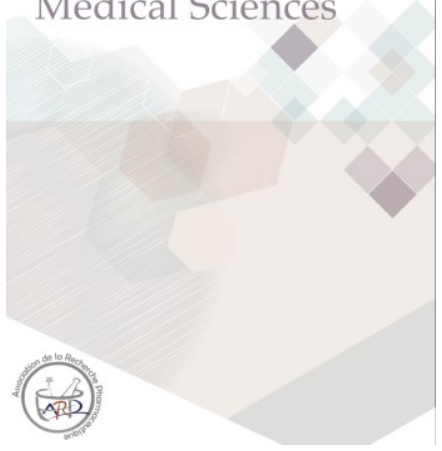

